Article

\title{
Essential Oil from Piper aduncum: Chemical Analysis, Antimicrobial Assessment, and Literature Review
}

\author{
Lianet Monzote ${ }^{1}$, Ramón Scull ${ }^{2}$, Paul $\operatorname{Cos}^{3}$ and William N. Setzer ${ }^{4, *}$ \\ 1 Parasitology Department, Institute of Tropical Medicine Pedro Kouri, 10400 Havana, Cuba; \\ monzote@ipk.sld.cu \\ 2 Department of Chemistry, Institute of Pharmacy and Food, University of Havana, 13600 Havana, Cuba; \\ rscull@ifal.ih.cu \\ 3 Laboratory for Microbiology, Parasitology and Hygiene, Faculty of Pharmaceutical, Biomedical and \\ Veterinary Sciences, Antwerp University, 2610 Wilrijk, Belgium; paul.cos@uantwerpen.be \\ 4 Department of Chemistry, University of Alabama in Huntsville, Huntsville, AL 35899, USA \\ * Correspondence: wsetzer@chemistry.uah.edu; Tel.: +1-256-824-6519
}

Academic Editor: Eleni Skaltsa

Received: 27 March 2017; Accepted: 28 June 2017; Published: 2 July 2017

\begin{abstract}
Background: The challenge in antimicrobial chemotherapy is to find safe and selective agents with potency that will not be compromised by previously developed resistance. Terrestrial plants could provide new leads to antibacterial, antifungal, or antiprotozoal activity. Methods: The essential oil (EO) of Piper aduncum L. (Piperaceae) from Cuba was analyzed by gas chromatography-mass spectrometry (GC-MS). A cluster analysis of P. aduncum EO compositions reported in the literature was carried out. The EO was screened against a panel of microorganisms (bacteria, fungi, parasitic protozoa) as well as for cytotoxicity against human cells. In addition, a review of scientific literature and a bibliometric study was also conducted. Results: A total of 90 compounds were identified in the EO, of which camphor $(17.1 \%)$, viridiflorol $(14.5 \%)$, and piperitone $(23.7 \%)$ were the main components. The cluster analysis revealed at least nine different chemotypes. The EO did not show notable activity against bacteria or fungi, but was active against parasitic protozoa. Conclusions: The results from this study indicate P. aduncum from Cuba is a unique chemotype, support the importance of P. aduncum EOs as medicines, and demonstrate the promise of Cuban P. aduncum EO as a chemotherapeutic agent against parasitic protozoal infections.
\end{abstract}

Keywords: Piper aduncum; essential oil; cluster analysis; chemotypes; antimicrobial; parasitic protozoa

\section{Introduction}

The challenge in antimicrobial chemotherapy is to find safe and selective agents with potency that will not be compromised by previously developed resistance. In this context, the search for new antimicrobial compounds from terrestrial plants could provide new leads to antibacterial, antifungal, or antiprotozoal activity. The World Health Organization also advocates the use of natural medicines for the treatment of microbial infectious agents. The search for new medicinal agents has become extremely important, and higher plants are a very rich source of new and selective substances with therapeutic potential against these ailments. There are approximately 250,000 plant species worldwide, of which only a fraction has so far been studied [1,2].

The Piperaceae family is distributed in tropical and subtropical regions in the northern and southern hemispheres and comprises around 3600 species. The Piper genus constitutes the most represented, with around 2000 species [3]. In particular, biological properties of essential oils (EOs) from Piper aduncum L. (Figure 1) have been widely studied, including antiprotozoal [4,5], anthelminthic [6], 
antioxidant [7], and insecticidal [8,9] activities. Considering these previously documented effects and the potentialities as therapeutic agents, we have focused on the EO from P. aduncum growing in Cuba. In this sense, chemical characterization of the EO was performed and the EO was also screened against a selection of microorganisms, including a Gram-negative (Escherichia coli) and a Gram-positive (Staphylococcus aureus) bacterium, a yeast (Candida albicans), and protozoa that are responsible for human parasitic infections: malaria (Plasmodium falciparum), sleeping sickness (Trypanosoma brucei), Chagas disease (T. cruzi), cutaneous (Leishmania amazonensis) and visceral (L. donovani and L. infantum) leishmaniasis. For comparison, in vitro cytotoxicity screening was performed on MRC-5 (normal human lung) cells. Finally, a summary of relevant aspect in the cited scientific literature of EO from P. aduncum was reviewed and a bibliometric study was also conducted.

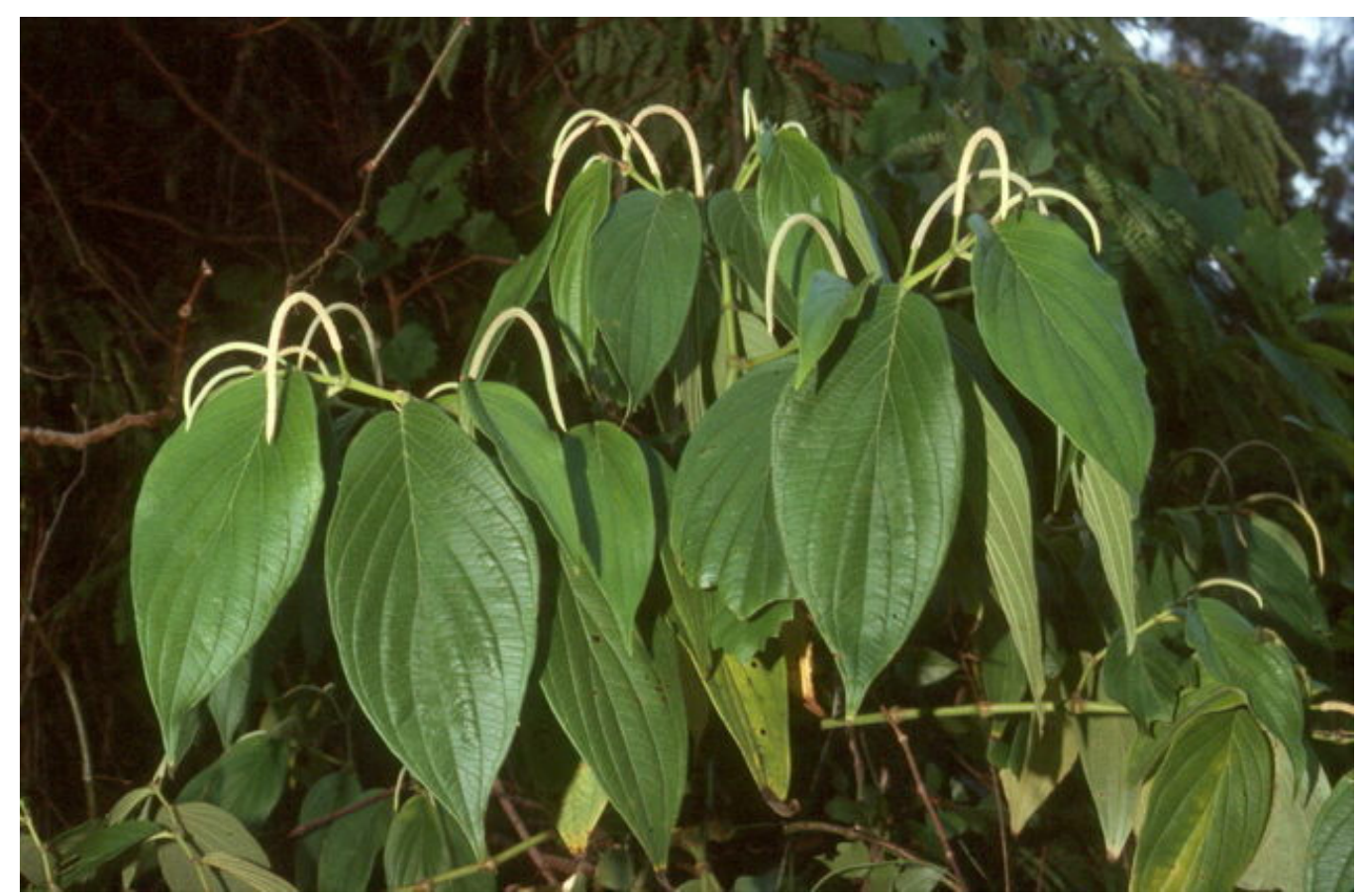

Figure 1. Photograph of Piper aduncum L. (@ Copyright Bobby Hattaway, 2011 [10]).

\section{Materials and Methods}

\subsection{Plant Material}

Aerial parts of P. aduncum were collected in the early morning of June 2010 from the Institute of Pharmacy and Food, Havana, Cuba. The plant was identified by M.Sc. Ramón Scull following the guidelines of the National Flora of Cuba; a voucher specimen was deposited in the Experimental Station of Medicinal Plants "Dr. Juan Tomás Roig”, Mayabeque, Cuba, under registration voucher number 4649. The fresh plant sample was manually crushed and the EO was immediately hydrodistilled by the conventional method using a Clevenger type apparatus for $5 \mathrm{~h}$, the oil was separated, and stored in an amber-colored glass bottle under refrigeration $\left(4{ }^{\circ} \mathrm{C}\right)$ prior to analysis. Solutions of the EO in dimethylsulfoxide (DMSO) were prepared $(20 \mathrm{mg} / \mathrm{mL})$ and used for biological evaluations (see below).

\subsection{Gas Chromatography-Mass Spectrometry}

Chemical characterization of the EO from $P$. aduncum was performed by gas chromatography/mass spectrometry using an Agilent 6890 gas chromatography (Agilent Technologies, Palo Alto, CA, USA) coupled with an Agilent 5973 mass selective detector (MSD) (Agilent Technologies, Palo Alto, CA, USA), operated in the electron impact (EI) mode with electron energy $=70 \mathrm{eV}$, a scan 
range of 40-400 amu, and a scan rate of 3.99 scans/s, and operated through an Agilent ChemStation data system (G1701CA, version C.00.01.080, Agilent Technologies, Palo Alto, CA, USA). The GC column was an HP-5ms fused silica capillary column (Agilent Technologies, Palo Alto, CA, USA), with (5\% phenyl)-polymethylsiloxane stationary phase, a film thickness of $0.25 \mu \mathrm{m}$, a length of $30 \mathrm{~m}$, and an internal diameter of $0.25 \mathrm{~mm}$. The carrier gas was helium with a column head pressure of $48.7 \mathrm{kPa}$ and a flow rate of $1.0 \mathrm{~mL} / \mathrm{min}$. The inlet temperature was $200{ }^{\circ} \mathrm{C}$, the interface temperature was $280{ }^{\circ} \mathrm{C}$, and the following GC oven temperature program was used: $40^{\circ} \mathrm{C}$ initial temperature, which was held for $10 \mathrm{~min}$; increased at $3{ }^{\circ} \mathrm{C} / \mathrm{min}$ to $200{ }^{\circ} \mathrm{C}$; increased $2{ }^{\circ} \mathrm{C} / \mathrm{min}$ to $220{ }^{\circ} \mathrm{C}$. A $1 \%$ w/v solution of the $\mathrm{EO}$ in $\mathrm{CH}_{2} \mathrm{Cl}_{2}$ was prepared and $1 \mu \mathrm{L}$ was injected using a splitless injection technique. Identification of the EO components was achieved using their retention indices (calculated relative to a homologous series of normal alkanes, and by comparison of their mass spectral fragmentation patterns with those reported in the literature [11] and our own in-house database. The percentages of the constituents were calculated from total ion current without standardization.

\subsection{Hierarchical Cluster Analysis}

A total of $38 \mathrm{EO}$ compositions of P. aduncum from the published literature, including the EO chemical makeup from this work, were treated as operational taxonomic units (OTUs). The percentages of 35 main essential oil compounds ( $\alpha$-pinene, $\beta$-pinene, myrcene, $\alpha$-terpinene, limonene, 1,8 -cineole, (Z)- $\beta$-ocimene, $(E)$ - $\beta$-ocimene, terpinolene, linalool, camphor, borneol, terpinen-4-ol, $\alpha$-terpineol, piperitone, $\alpha$-copaene, $\beta$-caryophyllene, aromadendrene, $\alpha$-humulene, germacrene $D$, valencene, asaricin, bicyclogermacrene, $\gamma$-cadinene, myristicin, $\delta$-cadinene, epi-longipinanol, $(E)$-nerolidol, longipinanol, spathulenol, caryophyllene oxide, viridiflorol, dill apiole, $\tau$-cadinol, and $\alpha$-cadinol) were used to determine the chemotypic characteristics of the various P. aduncum essential oil compositions by agglomerative hierarchical cluster (AHC) analysis using the XLSTAT software, version 2015.4.01 (Addinsoft $^{\mathrm{TM}}$, New York, NY, USA). To determine similarity, the Pearson correlation was used, and the clusters were defined using the unweighted pair-group method with arithmetic average (UPGMA).

\subsection{Bioactivity Evaluations}

\subsubsection{Reference Drugs}

Chloramphenicol and erythromycin were obtained from Sigma-Aldrich (Bornem, Belgium), while miconazole was generously donated by Janssen Pharmaceuticals (Beerse, Belgium). Benznidazol, chloroquine, miltefosine, and suramine were kindly donated by WHO-TDR and amphotericin B from Imefa (La Habana, Cuba).

\subsubsection{Microorganisms and Cell Culture}

Microorganisms used were: E. coli ATCC8739, S. aureus ATCC6538, C. albicans B59630, P. falciparum Ghana, T. b. brucei Squib-427, T. cruzi Tulahuen CL2, L. amazonensis MHOM/77BR/LTB0016, L. donovani $\mathrm{MHOM} / \mathrm{ET} / 67 / \mathrm{L} 82$, and L. infantum MHOM/MA(BE)/67. Cytotoxicity was tested against the mammalian cell line MRC-5 SV2 from the European Collection of Cell Cultures.

\subsubsection{Antimicrobial Tests}

The integrated panel of microbial screens for the present study and the standard screening methodologies were adopted as described by Cos et al. [12].

Escherichia coli and S. aureus were cultured in Mueller Hinton broth (MHB) medium, while C. albicans was cultured in RPMI medium. Assays were carried out by adding $5 \times 10^{3} \mathrm{CFU} /$ well. After $17 \mathrm{~h}$ incubation with different $\mathrm{EO}$ concentrations at $37^{\circ} \mathrm{C}$, bacterial or fungal viability was determined fluorimetrically after adding resazurin [13] for $30 \mathrm{~min}$ at $37^{\circ} \mathrm{C}$ to E. coli and S. aureus or $4 \mathrm{~h}$ at $37^{\circ} \mathrm{C}$ to $\mathrm{C}$. albicans. Fluorescence was measured using a GENios Tecan fluorimeter (Tecan Group Ltd., Männedorf, Switzerland) (excitation 530 nm, emission 590 nm). 
Plasmodium parasites were cultured in human erythrocytes $\mathrm{A}+$ at $37^{\circ} \mathrm{C}$ under an atmosphere of $3 \% \mathrm{O}_{2}, 4 \% \mathrm{CO}_{2}$, and $93 \% \mathrm{~N}_{2}$ [14] in RPMI- 1640 culture medium, supplemented with $0.5(\mathrm{~g} / \mathrm{v}) \%$ AlbumaxTM. Suspensions of infected human red blood cells (1\% parasitemia, 2\% hematocrit) were added to each well with the test EO and incubated for an additional $72 \mathrm{~h}$. The plate was then frozen at $-20^{\circ} \mathrm{C}$ and parasite multiplication was measured by the Malstat method [15]. One hundred microliters of Malstat ${ }^{\mathrm{TM}}$ reagent was transferred in a new plate and mixed with $20 \mu \mathrm{L}$ of the hemolysed parasite suspension for $15 \mathrm{~min}$ at room temperature. Then, $20 \mu \mathrm{L}$ of nitro blue tetrazolium chloride (NBT) at $2 \mathrm{mg} / \mathrm{mL} / \mathrm{PES}$ at $0.1 \mathrm{mg} / \mathrm{mL}$ solution was added and the plate was incubated again for $2 \mathrm{~h}$ at room temperature in the dark. Absorbance was read at $655 \mathrm{~nm}$ in a Bio-Rad 3550-UV microplate reader (Bio-Rad Laboratories, Hercules, CA, USA).

Antitrypanosomal activity was performed using trypomastigotes of T. brucei, cultured at $37^{\circ} \mathrm{C}$ and $5 \% \mathrm{CO}_{2}$ in Hirumi-9 medium [16], supplemented with $10 \%$ inactivated fetal calf serum (FCSi). Assays were performed by adding $1.5 \times 10^{4}$ trypomastigotes/well. After $72 \mathrm{~h}$ incubation, parasite growth was assessed fluorimetrically by adding resazurin for $24 \mathrm{~h}$ at $37^{\circ} \mathrm{C}$. In parallel, the EO at different concentrations was added to $4 \times 10^{4}$ amastigotes of $T$. cruzi in $4 \times 10^{3}$ MRC- 5 cells maintained in minimal essential medium (MEM) supplemented with $20 \mathrm{mM}$ L-glutamine, $16.5 \mathrm{mM}$ sodium bicarbonate, and $5 \% \mathrm{FCSi}$. After incubation at $37{ }^{\circ} \mathrm{C}$ and $5 \% \mathrm{CO}_{2}$ for 7 days, parasite growth was assessed by adding the $\beta$-galactosidase substrate chlorophenol red $\beta$-D-galactopyranoside [17] for $4 \mathrm{~h}$ at $37^{\circ} \mathrm{C}$ and the color reaction was read at $540 \mathrm{~nm}$.

Antileishmanial activity against the promastigote form of L. amazonensis and L. donovani were performed with exponentially growing cells $\left(10^{5}\right.$ promastigotes $/ \mathrm{mL}$ in $\left.199 \mu \mathrm{L}\right)$ in 96 -well plates. One microliter of EO at different concentrations were added and then incubated at $26^{\circ} \mathrm{C}$ for $72 \mathrm{~h}$. After $72 \mathrm{~h}$ of incubation, $20 \mu \mathrm{L}$ of $p$-nitrophenyl phosphate at $20 \mathrm{mg} / \mathrm{mL}$ and dissolved in $1 \mathrm{M}$ sodium acetate buffer, $1 \%$ Triton X-100, pH 5.5 were added to each well and the plate was incubated at $37^{\circ} \mathrm{C}$ for $3 \mathrm{~h}$. The absorbance was determined in an EMS Reader MF Version 2.4-0 (Labsystems Oy, Helsinki, Finland) at a wavelength of $405 \mathrm{~nm}$ [18]. In the case of experiment with L. infantum, amastigotes were obtained from an infected hamster and were used to infect primary peritoneal mouse macrophages $(\mathrm{PMM})$. Then, $3 \times 10^{4}$ macrophages were transferred to each well of a 96-well plate, and the plate was incubated for $48 \mathrm{~h}$ at $37^{\circ} \mathrm{C}$ and $5 \% \mathrm{CO}_{2}$. The cells were then washed and infected with L. infantum amastigotes at a density of 15 parasites per cell. After $2 \mathrm{~h}$ of infection, pre-diluted concentrations of EO were added to the plates, which were then incubated for an additional $120 \mathrm{~h}$ under the same conditions. The supernatant was then discarded, the cells were fixed with methanol, and stained with $10 \%$ Giemsa for microscopic analysis. The total parasite burden (equal to the average number of amastigotes per cell) in treated wells was determined for each well.

\subsubsection{Cytotoxicity Assay}

MRC- 5 cells were cultivated in MEM, supplemented with L-glutamine $(20 \mathrm{mM}), 16.5 \mathrm{mM}$ sodium hydrogen carbonate, and $5 \% \mathrm{FCSi}$ at $37{ }^{\circ} \mathrm{C}$ and $5 \% \mathrm{CO}_{2}$. For the assay, $10^{4} \mathrm{MRC}-5$ cells / well were seeded onto the test plates containing the pre-diluted $\mathrm{EO}$ at different concentrations and incubated at the same conditions for $72 \mathrm{~h}$. Cell viability was determined fluorimetrically $72 \mathrm{~h}$ after the addition of resazurin, as previously described (see above).

\subsubsection{Statistical Analysis}

In each case, the percentage growth inhibition for each concentration of EO was calculated compared to the untreated controls. The median inhibitory $\left(I C_{50}\right)$ and median cytotoxicity $\left(C C_{50}\right)$ concentration values were determined from the lineal concentration-response curves. Statistical differences between values were determined using Mann-Whitney with Statistica for Windows Program, Release 4.5, 1993 (StatSoft, Inc., Tulsa, OK, USA). 


\subsection{Literature Review}

\subsubsection{Bibliometric Study}

With the objective of obtaining reports about EOs from P. aduncum, an electronic search in PubMed [19] database was performed. Online access was on 30 January 2017 and the study period was from 1 January 1945 to 30 January 2017. The subject content analysis of records was conducted according to the Medical Subject Headings (MeSH), using the MeSH terms or descriptors 'Piper aduncum' and 'essential oil'. We did not restring any language or document type, in order to analyze publication patterns of all publications in the studied thematic.

The number of papers by year was obtained, as well as the language used and journals according to main topic. In addition, productivity by country was analyzed, considering only the institutional affiliation for the first participating author.

\subsubsection{Pharmacological and Chemical Reports}

The scientific reports previously obtained were screened and analyzed to identify and summarize the pharmacological and chemical studies of EOs from P. aduncum as well. The data extracted from the literature included country of collection, pharmacological application, and main chemical isolated compounds. In this case, there were also no exclusions related to publication dates or languages.

\section{Results and Discussion}

\subsection{Chemical Analysis of the Essential Oil from Piper aduncum}

A total of 90 compounds (Table 1) were found in the chromatogram of the EO obtained by gas chromatography coupled with mass spectrometry (GC-MS). The essential oil of P. aduncum from Cuba was dominated by oxygenated monoterpenoids $(50.3 \%)$ and oxygenated sesquiterpenoids (29.2\%), followed by monoterpene hydrocarbons (9.7\%) and sesquiterpene hydrocarbons (8.2\%), and an unidentified diterpenoid (2.0\%). Piperitone, camphor, and viridiflorol (Figure 2) were the main components with $23.7 \%, 17.1 \%$, and $14.5 \%$, respectively.<smiles>CC1=CC(=O)C(C(C)C)CC1</smiles>

Piperitone<smiles>CC12CCC(CC1=O)C2(C)C</smiles>

Camphor

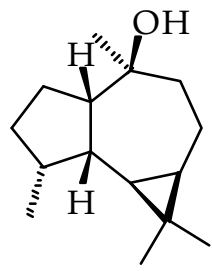

Viridiflorol

Figure 2. Chemical structures of the major components identified in the essential oil from Piper aduncum L. collected in Havana, Cuba.

Table 1. Chemical composition of essential oil from Piper aduncum L. collected in Havana, Cuba.

\begin{tabular}{ccllcc}
\hline RI & Compound & $\%$ & RI & Compound & $\%$ \\
\hline 789 & 3-Methyl-2-butenal & $\operatorname{tr}$ & 1337 & $\delta$-Elemene & 0.1 \\
858 & (3Z)-Hexenol & $\operatorname{tr}$ & 1349 & $\alpha$-Cubebene & $\operatorname{tr}$ \\
932 & Tricyclene & $\operatorname{tr}$ & 1366 & Cyclosativene & 0.1 \\
942 & $\alpha$-Pinene & 0.8 & 1371 & $\alpha$-Ylangene & 0.1 \\
954 & Camphene & 5.9 & 1376 & $\alpha$-Copaene & 0.5 \\
979 & $\beta$-Pinene & 0.4 & 1384 & $\beta$-Bourbonene & $\operatorname{tr}$ \\
989 & 6-Methyl-5-hepten-2-one & $\operatorname{tr}$ & 1393 & $\beta$-Elemene & 1.2 \\
993 & Myrcene & 0.1 & 1419 & $\beta$-Funebrene & $\operatorname{tr}$ \\
1005 & $\alpha$-Phellandrene & $\operatorname{tr}$ & 1420 & $\alpha$-Santalene & 0.2 \\
\hline
\end{tabular}


Table 1. Cont.

\begin{tabular}{|c|c|c|c|c|c|}
\hline RI & Compound & $\%$ & RI & Compound & $\%$ \\
\hline 1025 & $p$-Cymene & 1.0 & 1424 & Carvone hydrate & $\operatorname{tr}$ \\
\hline 1028 & Limonene & 1.5 & 1429 & $\beta$-Copaene & 0.2 \\
\hline 1031 & 1,8-Cineole & 0.1 & 1436 & $\alpha$-trans-Bergamotene & $\operatorname{tr}$ \\
\hline 1072 & cis-Linalool oxide (furanoid) & 0.1 & 1439 & Aromadendrene & 0.8 \\
\hline 1083 & Camphenilone & $\operatorname{tr}$ & 1453 & $\alpha$-Humulene & $\operatorname{tr}$ \\
\hline 1088 & Fenchone & 0.1 & 1461 & $\beta$-Santalene & 0.5 \\
\hline 1089 & trans-Linalool oxide (furanoid) & 0.1 & 1464 & $\alpha$-Acoradiene & $\operatorname{tr}$ \\
\hline 1101 & Linalool & 1.2 & 1475 & $\alpha$-Neocallitropsene & $\operatorname{tr}$ \\
\hline 1121 & cis-p-Menth-2-en-1-ol & $\operatorname{tr}$ & 1478 & $\gamma$-Muurolene & 1.0 \\
\hline 1126 & $\alpha$-Campholenal & $\operatorname{tr}$ & 1481 & $\gamma$-Curcumene & 0.1 \\
\hline 1136 & cis- $p$-Mentha-2,8-dien-1-ol & $\operatorname{tr}$ & 1484 & ar-Curcumene & 0.4 \\
\hline 1139 & trans-Pinocarveol & 0.1 & 1487 & $\beta$-Selinene & 0.6 \\
\hline 1140 & trans-p-Menth-2-en-1-ol & $\operatorname{tr}$ & 1496 & Viridiflorene & 0.4 \\
\hline 1144 & Camphor & 17.1 & 1502 & $\alpha$-Muurolene & 0.5 \\
\hline 1147 & Camphene hydrate & 0.5 & 1514 & $\beta$-Curcumene & $\operatorname{tr}$ \\
\hline 1156 & Isoborneol & 3.6 & 1515 & $\gamma$-Cadinene & 1.1 \\
\hline 1162 & Pinocarvone & 0.1 & 1534 & trans-Cadina-1,4-diene & $\operatorname{tr}$ \\
\hline 1165 & Borneol & 0.4 & 1537 & $\alpha$-Cadinene & 0.1 \\
\hline 1176 & Terpinen-4-ol & 0.2 & 1545 & $\alpha$-Calacorene & 0.4 \\
\hline 1183 & $p$-Methylacetophenone & $\operatorname{tr}$ & 1551 & Elemol & $\operatorname{tr}$ \\
\hline 1185 & Cryptone & 0.5 & 1553 & (Z)-Caryophyllene oxide & 0.2 \\
\hline 1190 & $\alpha$-Terpineol & 0.7 & 1567 & $(E)$-Nerolidol & 0.2 \\
\hline 1195 & Myrtenal & 0.1 & 1569 & Palustrol & 0.8 \\
\hline 1207 & trans-Piperitol & 0.1 & 1580 & Spathulenol & 1.3 \\
\hline 1218 & trans-Carveol & 0.1 & 1584 & Caryophyllene oxide & 3.7 \\
\hline 1225 & Bornylformate & 0.1 & 1595 & Viridiflorol & 14.5 \\
\hline 1232 & Isobornylformate & 0.6 & 1605 & Ledol & 0.9 \\
\hline 1237 & Cuminaldehyde & 0.1 & 1610 & Humulene epoxide II & 1.5 \\
\hline 1241 & Carvone & 0.1 & 1616 & 1,10-di-epi-Cubenol & 0.4 \\
\hline 1245 & Thymoquinone & $\operatorname{tr}$ & 1629 & 1-epi-Cubenol & 0.9 \\
\hline 1256 & Piperitone & 23.7 & 1638 & Caryophylla-4(12),8(13)-dien-5 $\beta$-ol & 0.3 \\
\hline 1286 & Bornyl acetate & 0.1 & 1642 & $\tau$-Cadinol & 1.3 \\
\hline 1291 & p-Cymen-7-ol & $\operatorname{tr}$ & 1644 & $\tau$-Muurolol & 0.9 \\
\hline 1293 & Thymol & 0.1 & 1647 & $\alpha$-Muurolol (=Torreyol) & 0.5 \\
\hline 1302 & 4-Hydroxy- $p$-menth-1-en-3-one & 0.5 & 1656 & $\alpha$-Cadinol & 1.9 \\
\hline 1316 & 4-Hydroxycryptone & 0.1 & 2285 & Unidentified diterpenoid & 2.0 \\
\hline
\end{tabular}

RI: "Retention Index", determined with respect to a homologous series of $n$-alkanes on an HP-5ms column.

In perusing the P. aduncum essential oil literature [7,8,20-32], there is a large degree of variation in compositions of the essential oils. Therefore, a hierarchical cluster analysis of the essential oil compositions was carried out (Figure 3). From the cluster analysis, we can define several different chemotypes: (1) a dill apiole chemotype; (2) a 1,8-cineole chemotype; (3) a (E)-nerolidol chemotype; (4) a linalool chemotype; (5) a $\beta$-caryophyllene chemotype; (6) a (E)- $\beta$-ocimene chemotype, and three mixed chemotypes rich in piperitone; (7) a piperitone/camphor chemotype; (8) a piperitone/terpinen-4-ol chemotype; and (9) an asaricin/piperitone/(E)- $\beta$-ocimene chemotype. The sample from Cuba in this work belongs to the piperitone/camphor chemotype and is similar in composition to another P. aduncum sample from Cuba [7]. There does seem to be some geographical correlation with chemotype. For example, the samples from the same region of northeastern Brazil all belong to the nerolidol chemotype [31]. Although we cannot rule out bias based on compound identification, quantitation, or detection, it is unlikely to significantly affect the cluster; dill apiole, 1,8-cineole, and nerolidol are readily identifiable essential oil components. 


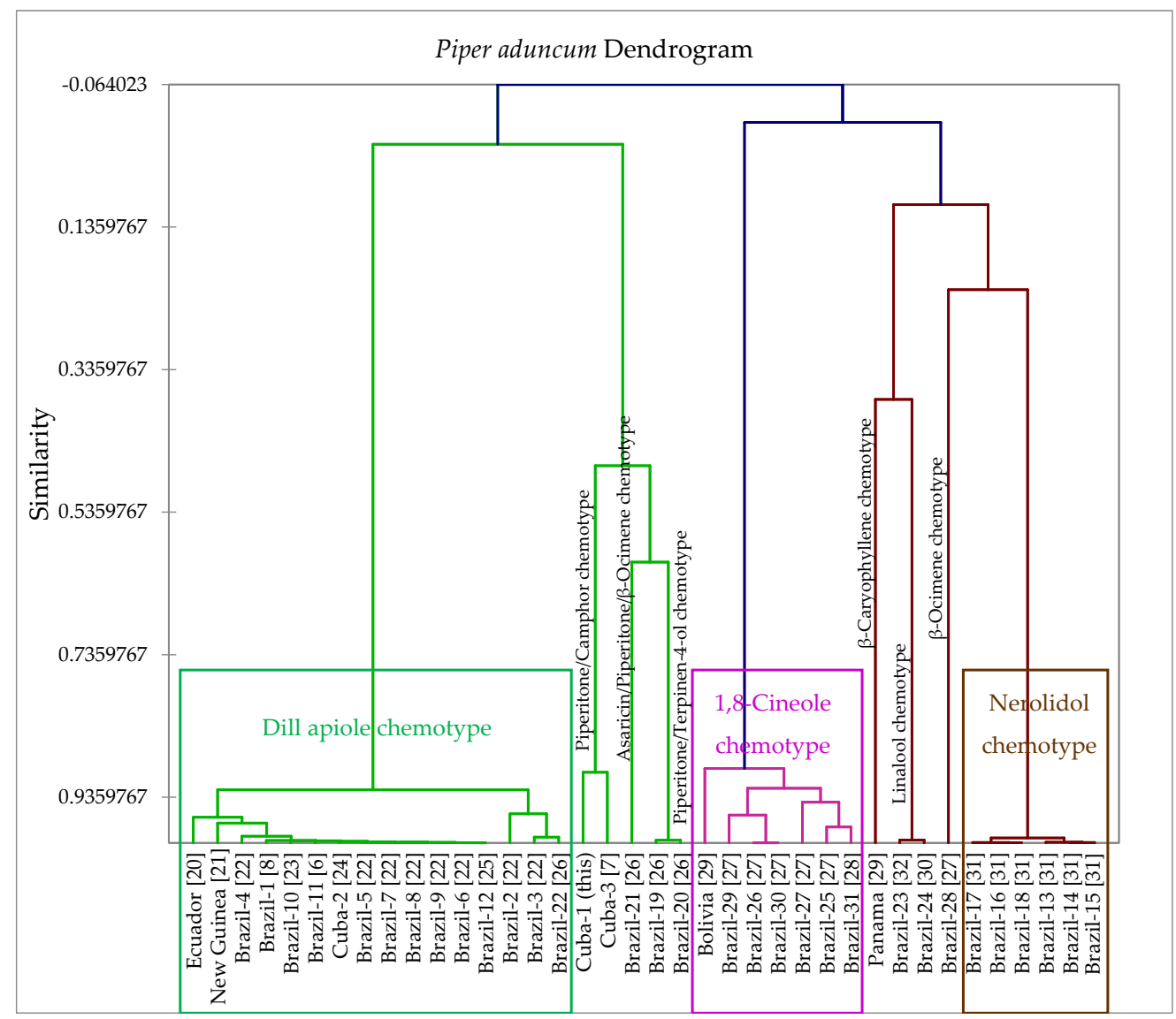

Figure 3. Dendrogram acquired from the agglomerative hierarchical cluster analysis of 38 Piper aduncum essential oil compositions.

\subsection{Antimicrobial Screening}

Several studies have indicated that EOs may be an antimicrobial alternative to antibiotics. In this sense, a wide panel of microorganisms that causes infectious diseases was included. In our study, the reference drugs caused a potent inhibition, as was expected, while different activities of P. aduncum EO were observed against the microorganisms tested. In the antibacterial and antifungal assays, the EO did not exhibit activity at $64 \mu \mathrm{g} / \mathrm{mL}$ (the highest concentration used), except against $S$. aureus, which did show some activity (Table 2). Currently, one of the widely used applications of EOs includes food preservatives, precisely due to their bactericidal and fungicidal properties [33-35]. However, the EO from P. aduncum in this work did not display high activity against human pathogenic bacteria and fungi.

Table 2. Antimicrobial activity, $I C_{50}(\mu \mathrm{g} / \mathrm{mL})$ of the essential oil from Piper aduncum $\mathrm{L}$. collected in Havana, Cuba.

\begin{tabular}{ccc}
\hline Bacteria & & \\
\hline & E. coli & S. aureus \\
\hline Piper aduncum oil & $>64$ & 18.2 \\
Reference drug & 0.8 & 8.3 \\
\hline Fungi & \multicolumn{2}{c}{ C. albicans } \\
\hline \multicolumn{2}{c}{$>64$} \\
Piper aduncum oil & 2.0 \\
Reference drug & \multicolumn{2}{c}{}
\end{tabular}

$I C_{50}$ : Median inhibitory concentration. Reference drugs: Chloramphenicol for E. coli, erythromycin for S. aureus and miconazole for C. albicans. 
In contrast, against protozoal parasites, the P. aduncum EO was able to inhibit all pathogens (Table 3). Parasitic protozoal infections cause much human morbidity and mortality. The prevalence of these diseases is higher in the tropics, where a significant number of deaths is attributed to malaria, leishmaniasis, African and American trypanosomiasis [36]—protozoal parasites that are included in this study. The best antiprotozoal activity of $P$. aduncum EO was observed against P. falciparum, the causal agent of malaria. Discovering new drugs in this field is a health priority because malaria is the major parasitic infection in many tropical and subtropical regions. Currently, more than one million deaths occur each year, and between 400 and 500 million new cases are reported annually; it is estimated that $40 \%$ of the world's population is at risk of malaria [37].

Table 3. Antiprotozoal activity, $I C_{50}(\mu \mathrm{g} / \mathrm{mL})$ of the essential oil from Piper aduncum $\mathrm{L}$. collected in Havana, Cuba.

\begin{tabular}{cccc}
\hline Sanguine Protozoa & & & \\
\hline & P. falciparum & T. brucei & T. cruzi \\
\hline Piper aduncum oil & 1.3 & 2.0 & 2.1 \\
Reference drug & 0.02 & 0.04 & 3.2 \\
\hline Leishmania spp. & & & \\
& L. amazonensis & L. donovani & L. infantum \\
\hline Piper aduncum oil & 23.8 & 7.7 & 8.1 \\
Reference drug & 0.02 & 0.03 & 3.7 \\
\hline
\end{tabular}

IC $C_{50}$ : Median inhibitory concentration. Reference drugs: Chloroquine for P. falciparum, suramine for T. brucei, benznidazol for T. cruzi, miltefosine for L. infantum, and amphotericin B for L. amazonensis and L. donovani.

In addition to the Plasmodium parasite, flagellated parasitic protozoa belonging to the genera Trypanosoma and Leishmania (Trypanosomatidae) were also included, which are considered Neglected Tropical Diseases (NTDs) by the World Health Organization [38]. In this sense, T. brucei is a causative agent of African trypanosomiasis or sleeping sickness, while T. cruzi causes American trypanosomiasis, commonly known as Chagas disease. Leishmaniasis exhibits a range of clinical appearances including cutaneous (CL), mucocutaneous (MCL), and visceral (VL) forms. In these human pathogenic trypanosomes, the management of the infections is currently based on chemotherapeutics that are not ideal due to cost, availability, toxicity, and resistance [39].

Among trypanosomes, both species of Trypanosoma were inhibited at the same concentration range with $\mathrm{IC}_{50}$ values around $2 \mu \mathrm{g} / \mathrm{mL}$. African trypanosomiasis invariably leads to coma and death if left untreated, with two stages. The first phase is characterized by nonspecific clinical symptoms, and trypanosomes are restricted to the lymphatic and circulatory systems, whereas in the second stage severe neurological symptoms appear, and parasites can be found in the brain and in cerebrospinal fluid [40]. It has been estimated that 60 million people in sub-Saharan Africa countries are currently at risk, and around 50,000 to 70,000 people are infected [39]. Chagas disease is present in Central and South America, with an annual death toll of about 50,000 people in 18 endemic countries, while more than 8 million people are infected, while nearly 90 million people are at risk of infection [41]. Recently, Villamizar and collaborators also demonstrated the antitrypanosomal activity of EO from P. aduncum collected in Brazil, showing an $I C_{50}$ of 2.8, 12.1, and $9 \mu \mathrm{g} / \mathrm{mL}$ against cell-derived, metacyclic trypomastigotes, and intracellular amastigotes, respectively [5]. In addition, they suggested that the probable mechanism of action was related with decreases in the mitochondrial membrane potential of the parasite after treatment [5].

Leishmania spp. showed variable susceptibilities to P. aduncum EO, with the species that cause visceral leishmaniasis (L. infantum and L. donovani) showing lower $I C_{50}$ values. In the clinical form of VL, the parasites colonize the bone marrow, liver, and spleen, resulting in host immunosuppression and death in the absence of treatment [39]. Finally, the species that causes CL (L. amazonensis), in which parasites remain localized in the epithelial tissues, the EO displayed a higher $I C_{50}$ value. Currently, leishmaniasis affects 12 million people in 98 countries where the disease is endemic and 350 million 
people live at risk of infection. In particular, the number of cases of VL is calculated to be as high as $0.2-0.4$ million people per year, with mortality estimated at $10-20 \%$, especially in poor areas [42]. Notably, Bernuci and collaborators reported that the EO from P. aduncum growing in Brazil displayed activity against L. amazonensis [43].

The antiprotozoal potential of $P$. aduncum essential oil has been demonstrated in this study. The activity may be attributed to the major components piperitone, camphor, and viridiflorol. Both piperitone and camphor have shown antiprotozoal activity against the bloodstream forms of Trypanosoma brucei brucei [44,45]. To our knowledge, however, there have been no reports on the antiprotozoal activity of viridiflorol. Nevertheless, the antiprotozoal activity of the Cuban P. aduncum chemotype EO shows promise, complements the reports of activity for other chemotypes of P. aduncum, and underscores the importance of EOs as potential treatment options for neglected tropical diseases.

In this present study, the cytotoxicity of $P$. aduncum EO was also studied using MRC-5 (Human fetal lung fibroblast) cells as a model. The EO inhibited cell growth, with an $I C_{50}$ value of $5.1 \mu \mathrm{g} / \mathrm{mL}$. Other authors also reported the cytotoxicity of EO from P. aduncum, in particular the EO collected in Brazil $[5,43]$. In this study, the reference drug tamoxifen also showed a high cytotoxic effect $\left(I C_{50}=\right.$ $4.3 \mu \mathrm{g} / \mathrm{mL})$.

\subsection{Literature Review}

\subsubsection{Bibliometric Study}

To carry out the bibliometric study we used the PubMed database, which is one of the most used databases by academics, medical students, and primary care practitioners according to several surveys. In addition, it is easily accessible and widely used, and it uses a controlled vocabulary for indexing and recovering documents with a certain criterion for quality [46-49].

A total of 20 articles were obtained, of which one was repeated, thus resulting in a total of 19 original reports about studies of EO from P. aduncum. Results in this field appear in the last decade, with a particular increase after 2010 (Figure 4). The language used was English in 15 scientific journals. The most used journal was Pest Management Science with three articles (16\%) followed by Molecules and Chemistry \& Biodiversity with two articles (11\%). The remaining journals published only one article each (5\%): Annals of Academia Brasileira Ciencia, Bulletin of Entomological Research, Experimental and Applied Acarology, Iranian Journal of Arthropod-Borne Diseases, Journal of the American Mosquito Control Association, Memórias do Instituto Oswaldo Cruz, Natural Product Communications, Neotropical Entomology, Pharmaceutical Biology, Revista Brasileira de Parasitologia Veterinária, Tropical Biomedicine and Veterinary Parasitology. The source journals mainly include the fields of vectors $>$ biology $>$ parasitology $>$ biomedicine. The first author's institutional address displayed that only four countries are involved in these studies, with different research groups. Brazil was the predominant country (63\%), followed by Cuba and Malaysia (16\%), and finally New Guinea (5\%).

This study has shown an increase in the number of publications on EOs from P. aduncum in recent years. A high representation in journals related to control of vectors was observed, which is in concordance with the main applications reported for Piper essential oils. In addition, the most representative country was Brazil, probably due to the exuberant flora, traditional use of natural products and the technical development of several research groups in the country in the field of chemistry and pharmacology. The bibliometric methodology used may present some limitations and further databases such as Science Direct and Scielo could be analyzed to search for additional studies. Nevertheless, this study represents a useful tool for scientists that are planning to study the EO from P. aduncum and could be used to help organize research in the field of EO and natural products in general. 


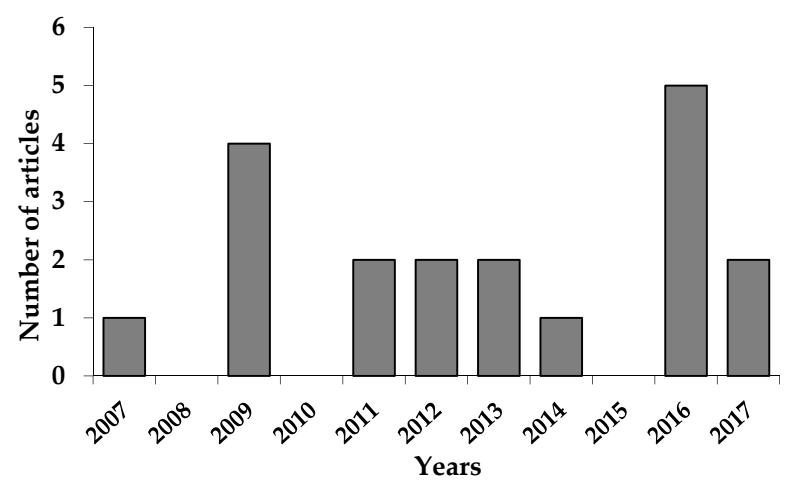

Figure 4. Number of articles found in PubMed database regarding essential oils from Piper aduncum L. by year $(n=19)$.

\subsubsection{Pharmacological and Chemical Reports}

The earlier analyses of scientific reports about the EO from P. aduncum indicated that insecticidal and antiparasitic activities have been the most reported of plants collected in tropical countries (Table 4). In the case of vectors, useful applications were found against Aedes aegypti mosquitoes, the vector of dengue and yellow fever. Antiparasitic effects were more studied against kinetoplastids, including Trypanosoma and Leishmania.

Table 4. Pharmacological reports of essential oil from Piper aduncum L. according to geographical location.

\begin{tabular}{ccc}
\hline Country & Pharmacological Activities (Description) & Reference \\
\hline Brazil & Acaricidal activity against Rhipicephalus microplus & {$[50]$} \\
& Acaricidal activity against Tetranychus urticae & {$[23]$} \\
& Insecticidal effect against Solenopsis saevissima & {$[8]$} \\
& Insecticidal effect against A. aegypti & {$[51]$} \\
& Insecticidal effect against Diaphorina citri & {$[52]$} \\
& Insecticidal effect against Euschistus heros & {$[53]$} \\
& Antiprotozoal activity against L. amazonensis & {$[43]$} \\
& Antibacterial activity against Mycobacterium tuberculosis & {$[5]$} \\
\hline Cuba & Antiprotozoal activity against T. cruzi & {$[7]$} \\
& Antioxidant activity & {$[6]$} \\
& Anthelminthic activity against Haemonchus contortus & {$[54]$} \\
\hline Antimicrobial activity against S. aureus, P. falciparum, T. & {$[55]$} \\
& cruzi, T. brucei, L. amazonensis and L. infantum & {$[56]$} \\
& Insect repellent against A. albopictus & {$[57]$} \\
& Insecticidal effect against Periplaneta americana & {$[9]$} \\
\hline
\end{tabular}

Several different components have been identified in EOs from P. aduncum. In general, between 23 and 68 compounds have been reported, with a higher percentage of monoterpenes. Unfortunately, many pharmacological studies did not include a chemical characterization of the EO. Some chemical compounds have been identified, isolated, and studied (Table 5). The most representative was the dill apiole, a phenylpropanoid, which showed antifungal, insecticidal, and anti-inflammatory activities. 
Table 5. Major chemical constituents reported for essential oils of Piper aduncum L.

\begin{tabular}{cccc}
\hline Major components & Pharmacological Activities $^{\text {a }}$ & Country & Reference \\
\hline 1,8-Cineole & - & Brazil & {$[28]$} \\
Apiole & - & New Guinea & {$[21]$} \\
Bicyclogermacrene & - & Brazil & {$[43]$} \\
Piperitone & - & Cuba & {$[7,54]$} \\
Dill apiole & Antifungal & Brazil & {$[25]$} \\
& Insecticidal & Brazil & {$[8,25,52]$} \\
& Anti-inflammatory & Brazil & {$[58]$} \\
Linalool & Genotoxic & Brazil & {$[59]$} \\
Nerolidol & Trypanocidal & Brazil & {$[5]$} \\
Safrole & Trypanocidal & Brazil & {$[5]$} \\
& Anti-inflammatory & Brazil & {$[58]$} \\
\hline
\end{tabular}

a Pharmacological activity was only included if pure compound was tested.

\section{Conclusions}

The results of this study support the importance of the EO from P. aduncum, in particular in regard to antiparasitic activity. Its effect against $P$. falciparum indicates that this EO could be a promising antimalarial agent. Further studies including in vivo bioassays are needed to validate the in vitro results and to ascertain the safety of the EO. In addition, the antimicrobial evaluation of the major components, camphor, viridiflorol, and piperitone, will be useful and will surely provide complementary data about antiparasitic active compounds as well as the mechanism(s) of action. There is significant chemical diversity in the EOs of P. aduncum, and this, no doubt, will affect the biological activities. Thus, there is a need to characterize the EOs of this plant and correlate this information with bioactivities.

Acknowledgments: This work was performed as part of the activities of the Research Network Natural Products against Neglected Diseases (ResNetNPND) [60].

Author Contributions: L.M. and W.N.S. designed the study, carried out the literature search, and wrote the manuscript. W.N.S. performed the chemical analysis, L.M. and P.C. performed the biological experiments, and R.S. collected the specimen and extracted the essential oil.

Conflicts of Interest: The authors declare no conflicts of interest.

\section{References}

1. Sen, R.; Chatterjee, M. Plant derived therapeutics for the treatment of Leishmaniasis. Phytomedicine 2011, 18, 1056-1069. [CrossRef] [PubMed]

2. Tiuman, T.S.; Santos, A.O.; Ueda-Nakamura, T.; Filho, B.P.D.; Nakamura, C.V. Recent advances in leishmaniasis treatment. Int. J. Infect. Dis. 2011, 15, e525-e532. [CrossRef] [PubMed]

3. Prando, T.B.L.; da Baciquete, T.F.; Vieira, J.A.C.; Bressan, J.; Gasparotto, F.M.; Jesus, D.R.; Cardozo Junior, E.L.; Lourenço, E.L.B.; Gasparotto Junior, A. Amides from Piper as a diuretic: Behind the ethnopharmacological uses of Piper glabratum Kunth. Evid.-Based Complement. Altern. Med. 2014. [CrossRef] [PubMed]

4. Monzote Fidalgo, L.; Sariego Ramos, I.; Montalvo Álvarez, A.M.; Garrido Lorente, N.; Scull Lizama, R.; Abreu Payrol, J. Propiedades antiprotozoarias de aceites esenciales extraídos de plantas Cubanas. Revis. Cuba. Med. Trop. 2004, 56, 230-233.

5. Villamizar, L.H.; das Graças Cardoso, M.; de Andrade, J.; Teixeira, M.L.; Soares, M.J. Linalool, a Piper aduncum essential oil component, has selective activity against Trypanosoma cruzi trypomastigote forms at $4{ }^{\circ} \mathrm{C}$. Mem. Inst. Oswaldo Cruz 2017, 112, 131-139. [CrossRef] [PubMed]

6. Gaínza, Y.A.; Fantatto, R.R.; Chaves, F.C.M.; Bizzo, H.R.; Esteves, S.N.; Chagas, A.C.; Gaínza, Y.A.; Fantatto, R.R.; Chaves, F.C.M.; Bizzo, H.R.; et al. Piper aduncum against Haemonchus contortus isolates: Cross resistance and the research of natural bioactive compounds. Revis. Bras. Parasitol. Vet. 2016, 25, 383-393. [CrossRef] [PubMed] 
7. Rodriguez, E.J.; Saucedo-Hernández, Y.; Vander Heyden, Y.; Simó-Alfonso, E.F.; Ramis-Ramos, G.; Lerma-García, M.J.; Monteagudo, U.; Bravo, L.; Medinilla, M.; de Armas, Y.; et al. Chemical analysis and antioxidant activity of the essential oils of three Piperaceae species growing in the central region of Cuba. Nat. Prod. Commun. 2013, 8, 1325-1328. [PubMed]

8. Souto, R.N.P.; Harada, A.Y.; Andrade, E.H.A.; Maia, J.G.S. Insecticidal activity of Piper essential oils from the Amazon against the fire ant Solenopsis saevissima (Smith) (Hymenoptera: Formicidae). Neotrop. Entomol. 2012, 41, 510-517. [CrossRef] [PubMed]

9. Mamood, S.N.H.; Hidayatulfathi, O.; Budin, S.B.; Ahmad Rohi, G. The formulation of the essential oil of Piper aduncum Linnaeus (Piperales: Piperaceae) increases its efficacy as an insect repellent. Bull. Entomol. Res. 2017, 107, 49-57. [CrossRef] [PubMed]

10. Discover Life's copyright policy \& terms of use. Available online: http://www.discoverlife.org/ap/ copyright.html (accessed on 1 July 2017).

11. Adams, R.P. Identification of Essential Oil Components by Gas Chromatography/Mass Spectrometry, 4th ed.; Allured Publishing: Carol Stream, IL, USA, 2007.

12. Cos, P.; Vlietinck, A.J.; Berghe, D.V.; Maes, L. Anti-infective potential of natural products: How to develop a stronger in vitro "proof-of-concept". J. Ethnopharmacol. 2006, 106, 290-302. [CrossRef] [PubMed]

13. Räz, B.; Iten, M.; Grether-Bühler, Y.; Kaminsky, R.; Brun, R. The Alamar Blue®assay to determine drug sensitivity of African trypanosomes (T. b. rhodesiense and T. b. gambiense) in vitro. Acta Trop. 1997, 68, $139-147$. [CrossRef]

14. Trager, W.; Jensen, J.B. Human malaria parasites in continuous culture. J. Parasitol. 2005, 91, 484-486. [CrossRef]

15. Makler, M.T.; Ries, J.M.; Williams, J.A.; Bancroft, J.E.; Piper, R.C.; Gibbins, B.L.; Hinrichs, D.J. Parasite lactate dehydrogenase as an assay for Plasmodium falciparum drug sensitivity. Am. J. Trop. Med. Hyg. 1993, 48, 739-741. [CrossRef] [PubMed]

16. Hirumi, H.; Hirumi, K. Continuous cultivation of Trypanosoma brucei blood stream forms in a medium containing a low concentration of serum protein without feeder cell layers. J. Parasitol. 1989, 75, 985-989. [CrossRef] [PubMed]

17. Buckner, F.S.; Verlinde, C.L.M.J.; La Flamme, A.C.; van Voorhis, W.C. Efficient technique for screening drugs for activity against Trypanosoma cruzi using parasites expressing $\beta$-galactosidase. Antimicrob. Agents Chemother. 1996, 40, 2592-2597. [PubMed]

18. Bodley, A.L.; McGarry, M.W.; Shapiro, T.A. Drug cytotoxicity assay for African trypanosomes and Leishmania species. J. Infect. Dis. 1995, 172, 1157-1159. [CrossRef] [PubMed]

19. PubMed. Available online: http://www.ncbi.nlm.nih.gov/pubmed (accessed on 27 March 2017).

20. Guerrini, A.; Sacchetti, G.; Rossi, D.; Paganetto, G.; Muzzoli, M.; Andreotti, E.; Tognolini, M.; Maldonado, M.E.; Bruni, R. Bioactivities of Piper aduncum L. and Piper obliquum Ruiz \& Pavon (Piperaceae) essential oils from eastern Ecuador. Environ. Toxicol. Pharmacol. 2009, 27, 39-48. [PubMed]

21. Rali, T.; Wossa, S.W.; Leach, D.N.; Waterman, P.G. Volatile chemical constituents of Piper aduncum L and Piper gibbilimbum C. DC (Piperaceae) from Papua New Guinea. Molecules 2007, 12, 389-394. [CrossRef] [PubMed]

22. Maia, J.G.S.; Zoghbi, M.G.B.; Andrade, E.H.A.; Santos, A.S.; da Silva, M.H.; Luz, A.I.R.; Bastos, C.N. Constituents of the essential oil of Piper aduncum L. growing wild in the Amazon region. Flavour Fragr. J. 1998, 13, 269-272. [CrossRef]

23. Araújo, M.J.C.; Câmara, C.A.G.; Born, F.S.; Moraes, M.M.; Badji, C.A. Acaricidal activity and repellency of essential oil from Piper aduncum and its components against Tetranychus urticae. Exp. Appl. Acarol. 2012, 57, 139-155. [CrossRef] [PubMed]

24. Pino, J.A.; Marbot, R.; Bello, A.; Urquiola, A. Essential oils of Piper peltata (L.) Miq. and Piper aduncum L. from Cuba. J. Essent. Oil Res. 2004, 16, 124-126. [CrossRef]

25. De Almeida, R.R.P.; Souto, R.N.P.; Bastos, C.N.; da Silva, M.H.L.; Maia, J.G.S. Chemical variation in Piper aduncum and biological properties of its dillapiole-rich essential oil. Chem. Biodivers. 2009, 6, 1427-1434. [CrossRef] [PubMed]

26. Potzernheim, M.C.L.; Bizzo, H.R.; Silva, J.P.; Vieira, R.F. Chemical characterization of essential oil constituents of four populations of Piper aduncum L. from Distrito Federal, Brazil. Biochem. Syst. Ecol. 2012, 42, $25-31$. [CrossRef] 
27. Oliveira, G.L.; de Moreira, D.L.; Mendes, A.D.R.; Guimarães, E.F.; Figueiredo, L.S.; Kaplan, M.A.C.; Martins, E.R. Growth study and essential oil analysis of Piper aduncum from two sites of Cerrado biome of Minas Gerais State, Brazil. Braz. J. Pharmacogn. 2013, 23, 743-753. [CrossRef]

28. Oliveira, G.L.; Vieira, T.M.; Nunes, V.F.; de Ruas, M.O.; Duarte, E.R.; de Moreira, D.L.; Kaplan, M.A.C.; Martins, E.R. Chemical composition and efficacy in the egg-hatching inhibition of essential oil of Piper aduncum against Haemonchus contortus from sheep. Braz. J. Pharmacogn. 2014, 24, 288-292. [CrossRef]

29. Vila, R.; Tomi, F.; Mundina, M.; Santana, A.I.; Solís, P.N.; López Arce, J.B.; Balderrama Iclina, J.L.; Iglesias, J.; Gupta, M.P.; Casanova, J.; et al. Unusual composition of the essential oils from the leaves of Piper aduncum. Flavour Fragr. J. 2005, 20, 67-69. [CrossRef]

30. Morandim-Giannetti, A.A.; Pin, A.R.; Pietro, N.A.S.; de Oliveira, H.C.; Mendes-Giannini, M.J.S.; Alecio, A.C.; Kato, M.J.; de Oliveira, J.E.; Furlan, M. Composition and antifungal activity against Candida albicans, Candida parapsilosis, Candida krusei and Cryptococcus neoformans of essential oils from leaves of Piper and Peperomia species. J. Med. Plants Res. 2010, 4, 1810-1814.

31. De Oliveira, J.C.S.; Dias, I.J.M.; da Camara, C.A.G.; Schwartz, M.O.E. Volatile constituents of the leaf oils of Piper aduncum L from different regions of Pernambuco (northeast of Brazil). J. Essent. Oil Res. 2006, 18, 557-559. [CrossRef]

32. Navickiene, H.M.D.; de Morandim, A.A.; Alécio, A.C.; Regasini, L.O.; Bergamo, D.C.B.; Telascrea, M.; Cavalheiro, A.J.; Lopes, M.N.; Bolzani, V.S.; Furlan, M.; et al. Composition and antifungal activity of essential oils from Piper aduncum, Piper arboreum and Piper tuberculatum. Quim. Nova 2006, 29, 467-470. [CrossRef]

33. Bakkali, F.; Averbeck, S.; Averbeck, D.; Idaomar, M. Biological effects of essential oils-A review. Food Chem. Toxicol. 2008, 46, 446-475. [CrossRef] [PubMed]

34. Tiwari, B.K.; Valdramidis, V.P.; O’Donnell, C.P.; Muthukumarappan, K.; Bourke, P.; Cullen, P.J. Application of natural antimicrobials for food preservation. J. Agric. Food Chem. 2009, 57, 5987-6000. [CrossRef] [PubMed]

35. Adorjan, B.; Buchbauer, G. Biological properties of essential oils: An updated review. Flavour Fragr. J. 2010, 26, 407-426. [CrossRef]

36. Pink, R.; Hudson, A.; Mouriès, M.-A.; Bendig, M. Opportunities and challenges in antiparasitic drug discovery. Nat. Rev. Drug Discov. 2005, 4, 727-740. [CrossRef] [PubMed]

37. World Health Organization; UNICEF. World Malaria Report, 2005; World Health Organization: Geneva, Switzerland, 2005.

38. World Health Organization. Third WHO Report on Neglected Tropical Diseases 2015: Investing to Overcome the Global Impact of Neglected Tropical Diseases; World Health Organization: Geneva, Switzerland, 2015.

39. Zucca, M.; Scutera, S.; Savoia, D. New chemotherapeutic strategies against malaria, leishmaniasis and trypanosomiases. Curr. Med. Chem. 2013, 20, 502-526. [CrossRef] [PubMed]

40. Brun, R.; Blum, J.; Chappuis, F.; Burri, C. Human African trypanosomiasis. Lancet 2010, 375, $148-159$. [CrossRef]

41. Salomon, C.J. First century of Chagas' disease: An overview on novel approaches to nifurtimox and benznidazole delivery systems. J. Pharm. Sci. 2012, 101, 888-894. [CrossRef] [PubMed]

42. Alvar, J.; Vélez, I.D.; Bern, C.; Herrero, M.; Desjeux, P.; Cano, J.; Jannin, J.; de Boer, M. Leishmaniasis worldwide and global estimates of its incidence. PLoS ONE 2012, 7, e35671. [CrossRef] [PubMed]

43. Bernuci, K.; Iwanaga, C.; Fernadez-Andrade, C.; Lorenzetti, F.; Torres-Santos, E.; Faiões, V.; Gonçalves, J.; do Amaral, W.; Deschamps, C.; Scodro, R.; et al. Evaluation of chemical composition and antileishmanial and antituberculosis activities of essential oils of Piper species. Molecules 2016, 21, 1698. [CrossRef] [PubMed]

44. Monzote, L.; Alarcón, O.; Setzer, W.N. Antiprotozoal activity of essential oils. Agric. Conspec. Sci. 2012, 77, 167-175.

45. Schmidt, T.; Khalid, S.A.; Romanha, A.J.; Alves, T.M.; Biavatti, M.W.; Brun, R.; Da Costa, F.B.; de Castro, S.L.; Ferreira, V.F.; de Lacerda, M.V.G.; et al. The potential of secondary metabolites from plants as drugs or leads against protozoan neglected diseases-Part I. Curr. Med. Chem. 2012, 19, 2128-2175. [PubMed]

46. Tannery, N.H.; Foust, J.E.; Gregg, A.L.; Hartman, L.M.; Kuller, A.B.; Worona, P.; Tulsky, A.A. Use of Web-based library resources by medical students in community and ambulatory settings. J. Med. Libr. Assoc. 2002, 90, 305-309. [PubMed]

47. Cullen, R.J. In search of evidence: Family practitioners' use of the Internet for clinical information. J. Med. Libr. Assoc. 2002, 90, 370-379. [PubMed] 
48. De Groote, S.L.; Dorsch, J.L. Measuring use patterns of online journals and databases. J. Med. Libr. Assoc. 2003, 91, 231-240. [PubMed]

49. Rollin, L.; Darmoni, S.; Caillard, J.-F.; Gehanno, J.-F. Searching for high-quality articles about intervention studies in occupational health—What is really missed when using only the Medline database? Scand. J. Work Environ. Health 2010, 36, 484-487. [CrossRef] [PubMed]

50. Silva, W.C.; de Souza Martins, J.R.; de Souza, H.E.M.; Heinzen, H.; Cesio, M.V.; Mato, M.; Albrecht, F.; de Azevedo, J.L.; de Barros, N.M. Toxicity of Piper aduncum L. (Piperales: Piperaceae) from the Amazon forest for the cattle tick Rhipicephalus (Boophilus) microplus (Acari: Ixodidae). Vet. Parasitol. 2009, 164, 267-274. [CrossRef] [PubMed]

51. Oliveira, G.L.; Cardoso, S.K.; Lara Júnior, C.R.; Vieira, T.M.; Guimarães, E.F.; Figueiredo, L.S.; Martins, E.R.; Moreira, D.L.; Kaplan, M.A.C. Chemical study and larvicidal activity against Aedes aegypti of essential oil of Piper aduncum L. (Piperaceae). An. Acad. Bras. Cienc. 2013, 85, 1227-1234. [CrossRef] [PubMed]

52. Volpe, H.X.; Fazolin, M.; Garcia, R.B.; Magnani, R.F.; Barbosa, J.C.; Miranda, M.P. Efficacy of essential oil of Piper aduncum against nymphs and adults of Diaphorina citri. Pest Manag. Sci. 2016, 72, 1242-1249. [CrossRef] [PubMed]

53. Turchen, L.M.; Piton, L.P.; Dall'Oglio, E.L.; Butnariu, A.R.; Pereira, M.J.B. Toxicity of Piper aduncum (Piperaceae) essential oil against Euschistus heros (F.) (Hemiptera: Pentatomidae) and non-effect on egg parasitoids. Neotrop. Entomol. 2016, 45, 604-611. [CrossRef] [PubMed]

54. Gutiérrez, Y.; Montes, R.; Scull, R.; Sánchez, A.; Cos, P.; Monzote, L.; Setzer, W.N. Chemodiversity associated with cytotoxicity and antimicrobial activity of Piper aduncum var. ossanum. Chem. Biodivers. 2016, 13, 1715-1719. [CrossRef] [PubMed]

55. Misni, N.; Sulaiman, S.; Othman, H.; Omar, B. Repellency of essential oil of Piper aduncum against Aedes albopictus in the laboratory. J. Am. Mosq. Control Assoc. 2009, 25, 442-447. [CrossRef] [PubMed]

56. Ling, A.I.; Sulaiman, S.; Othman, H. Evaluation of Piper aduncum Linn. essential oil (Fam: Piperaceae) against Periplaneta americana (L.). Iran. J. Arthropod-Borne Dis. 2009, 3, 1-6. [PubMed]

57. Misni, N.; Othman, H.; Sulaiman, S. The effect of Piper aduncum Linn. (Family: Piperaceae) essential oil as aerosol spray against Aedes aegypti (L.) and Aedes albopictus Skuse. Trop. Biomed. 2011, 28, 249-258. [PubMed]

58. Parise-Filho, R.; Pastrello, M.; Camerlingo, C.E.P.; Silva, G.J.; Agostinho, L.A.; da Souza, T. The anti-inflammatory activity of dillapiole and some semisynthetic analogues. Pharm. Biol. 2011, 49, 1173-1179. [CrossRef] [PubMed]

59. Aciole, E.H.P.; Guimarães, N.N.; Silva, A.S.; Amorim, E.M.; Nunomura, S.M.; Garcia, A.C.L.; Cunha, K.S.; Rohde, C. Genetic toxicity of dillapiol and spinosad larvicides in somatic cells of Drosophila melanogaster. Pest Manag. Sci. 2014, 70, 559-565. [CrossRef] [PubMed]

60. Network Natural Products against Neglected Diseases (ResNetNPND). Available online: http://www. resnetnpnd.org/Start/ (accessed on 28 March 2017). 